\title{
KLEM AKTIF TUNGGAL INTERLEAVED FLYBACK DENGAN KOMBINASI NMOSFET DAN P-MOSFET
}

\author{
Andriyatna Agung Kurniawan', Eka Firmansyah ${ }^{2}$, F. Danang Wijaya ${ }^{3}$ \\ 1,2,3 Departemen Teknik Elektro dan Teknologi Informasi \\ Fakultas Teknik \\ Universitas Gajah Mada \\ Email : andriyatna.sie14@mail.ugm.ac.id ${ }^{1}$,ekafirmansyah@gmail.com², \\ danangwijaya@te.ugm.ac.id ${ }^{3}$
}

\begin{abstract}
ABSTRAK
Penggunaan topologi interleaved flyback dengan menyusun dua atau lebih rangkaian flyback dapat mengakibatkan peningkatan dampak tegangan kejut. Dengan meningkatnya dampak tegangan kejut akan berakibat meningkatnya pula resiko kerusakan sistem akibat tegangan kejut tersebut. Dalam penelitian ini, diusulkan sebuah rangkaian klem aktif tunggal untuk mengatasi masalah tegangan kejut yang timbul dari dua buah flyback yang tersusun dalam konfigurasi interleaved. Selain untuk mengatasi tegangan kejut yang timbul, pemasangan klem aktif tunggal pada interleaved flyback juga mengurangi penggunaan komponen aktif dan pasif pada sistem sehingga dapat meningkatkan efisiensi dan mengurangi biaya produksi. Penelitian ini disimulasikan pada sistem area kerja $350 \mathrm{~W}$ dan dari simulasi diperoleh nilai efisiensi $91.8 \%$.
\end{abstract}

Kata Kunci: flyback, interleaved, klem, kejut.

\begin{abstract}
Interleaved flyback topology usage with two or more flyback circuits can cause an enhancement of voltage spike impact. It also can cause an enhancement of risk on damaging system it self. In this paper, a single active clamp circuit is proposed to overcome voltage spike in the interleaved flyback. Besides that, a single active clamp circuit on interleaved flyback also can reduce the use of active and passive components in the system in order to improve efficiency and reduce cost production. This research was simulated on work area system $350 \mathrm{~W}$. The result show that the efficience of propose is $91.8 \%$.
\end{abstract}

Keyword: flyback, interleaved, clamp, spike. 


\section{PENDAHULUAN}

Konverter dengan topologi flyback lebih menarik digunakan karena flyback relatif lebih simpel dibandingkan topologi lainnya (Watson, 1996). Untuk mengurangi ukuran konverter digunakanlah frekuensi pensaklaran yang tinggi, meskipun frekuensi pensaklaran yang rendah memiliki efisiensi energi yang lebih baik (Pinheiro, 2002). Untuk mengurangi ripple dan memperkecil ukuran filter, struktur interleaved diadopsi pada banyak konverter DC-DC (Chin, 1995).

Rangkaian klem aktif digunakan pada banyak konverter. Dengan klem aktif kebocoran energi dapat dipulihkan dan tegangan kejut pada saklar dapat dijepit (Wuhua, 2007). Tanpa penggunaan rangkaian klem aktif kebocoran energi dari trafo menyebabkan tegangan kejut yang tinggi pada MOSFET akibat fenomena resonansi yang terjadi antara kebocoran energi dan kapasitansi pada MOSFET (Parampreet, 2014).

Pada penelitian ini diusulkan konverter DC-DC bertopologi flyback yang disusun secara interleaved menggunakan rangkaian klem aktif tunggal. Timbulnya tegangan kejut pada masing-masing flyback diatasi dengan klem aktif tunggal sehingga mengurangi pemakaian sejumlah komponen aktif maupun pasif yang berdampak pada berkurangnya biaya produksi. Komponen yang dikurangi adalah jumlah pemakaian saklar dan kapasitor klem.

Adapun keunggulan dari penggunaan rangkaian ini adalah sebagai berikut :

- Mengurangi jumlah komponen rangkaian sehingga mengurangi jumlah biaya produksi.

- Menaikkan tegangan keluaran.

- Meningkatkan efisiensi energi.

- Mengurangi ripple tegangan.

Paper terdiri dari pendahuluan, desain rangkaian, operasi pada rangkaian, pensaklaran, simulasi, dan kesimpulan. 


\section{DESAIN RANGKAIAN}

\section{A. Interleaved flyback dengan rangkaian klem aktif konvensional dan} klem aktif tunggal.

Salah satu perhatian terbesar dari topologi flyback adalah bagaimana mengatasi energi yang bocor. Ketika flyback disusun secara interleaved. Flyback memiliki kelemahan yaitu timbulnya induktansi bocor yang mengakibatkan tegangan kejut. Hal ini terjadi saat saklar (MOSFET) kondisi mati, sejumlah besar energi masih terdapat pada inti yang belum tertransfer pada sisi sekunder. Energi tersebut menyebabkan tegangan kejut pada MOSFET yang dapat berpotensi besar merusakkan MOSFET.

Sebuah sirkuit klem aktif pada dasarnya merupakan sirkuit snubber tanpa rugi (AN-1444,2012). Konverter topologi interleaved flyback dengan rangkaian klem aktif konvensional ditampilkan pada Gambar. 1. Sirkuit klem aktif ini dipercaya dapat mengatasi tegangan kejut yang terjadi dengan menyimpannya pada kapasitor dan kemudian dapat digunakan pada tahap selanjutnya.

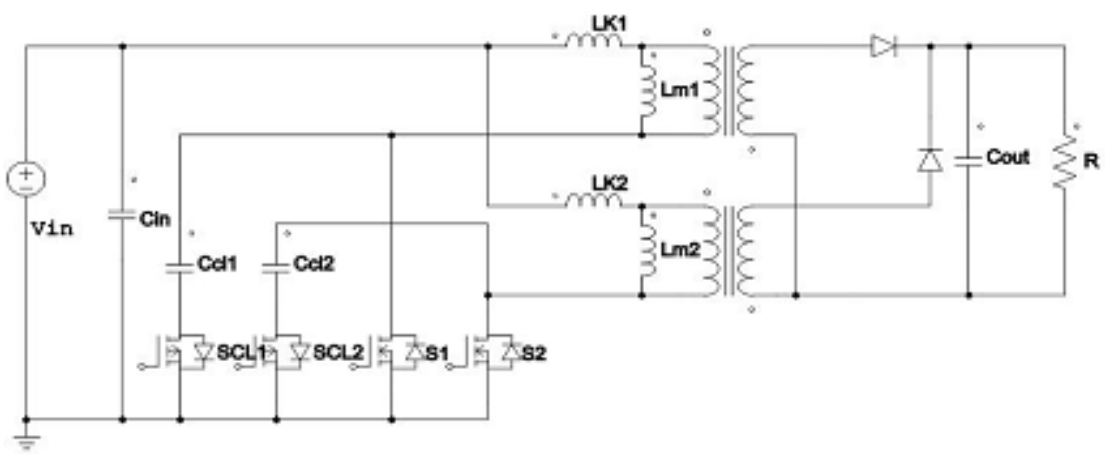

Gambar. 1. Rangkaian interleaved flyback dengan klem aktif konvensional 


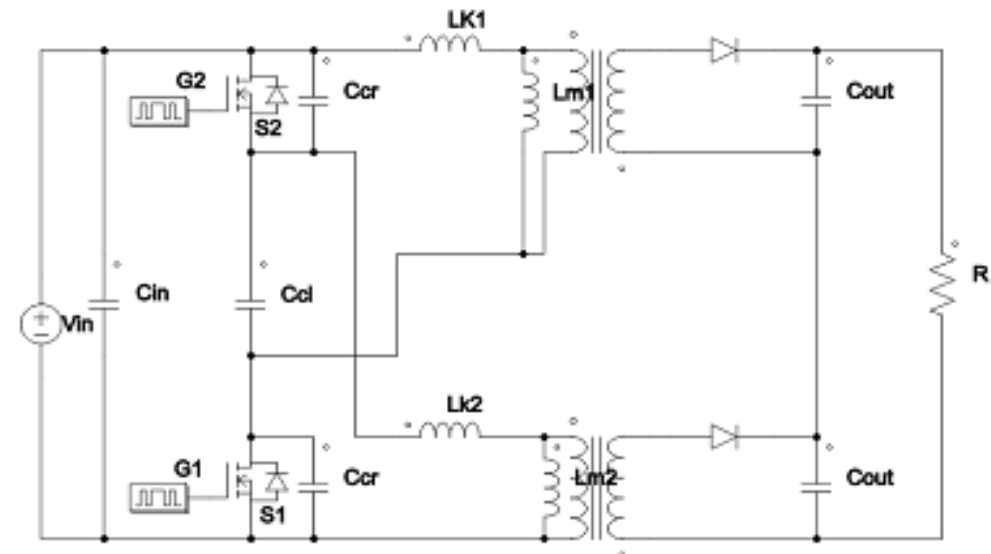

Gambar. 2. Rangkaian interleaved flyback dengan klem aktif tunggal pada penelitian (Alimadadi,2009).

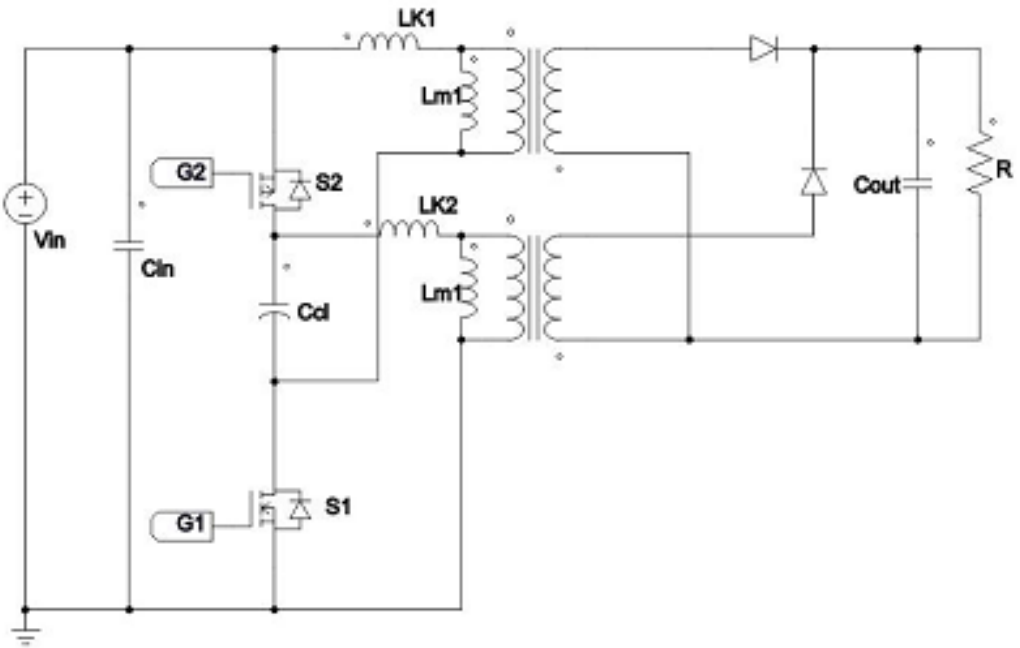

Gambar. 3. Rangkaian interleaved flyback dengan klem aktif tunggal yang diusulkan.

Penggunaan topologi flyback yang disusun interleaved maka sirkuit klem aktif yang dibutuhkan pada umumnya mengikuti jumlah dari flyback tersebut. Hal ini menyebabkan banyaknya jumlah komponen aktif dan pasif pada satu sistem rangkaian interleaved flyback yang harus dipasang. Diketahui bahwa setiap komponen aktif maupun pasif pasti memiliki rugi-rugi di dalamnya. Semakin banyak komponen yang dipasang maka akan semakin bertambah pula rugi-rugi yang terjadi pada sistem. 
Pada penelitian (Alimadadi,2009) telah diusulkan rangkaian interleaved flyback dengan klem aktif tunggal sebagaimana ditunjukkan pada Gambar. 2. Pada rangkaian tersebut hanya digunakan sebuah kapasitor klem yang saklarnya merupakan saklar utama (S1 dan S2) yang bekerja silih berganti. Rangkaian yang diusulkan pada penelitian (Alimadadi,2009) terbukti berhasil dalam mengatasi tegangan kejut dan menghasilkan efisiensi yang baik pada area daya keluaran 500W.

B. Interleaved flyback dengan rangkaian klem aktif tunggal yang diusulkan dengan P-MOSFET dan N-MOSFET.

Topologi yang dikenalkan pada penelitian (Alimadadi, 2009) hanya menggunakan sebuah kapasitor klem untuk mengatasi tegangan kejut pada dua buah flyback yang tersusun secara interleaved. Pengurangan komponen baik aktif maupun pasif terbukti menghasilkan efisiensi yang baik pada area kerja $500 \mathrm{~W}$.

Pada penelitian ini disimulasikan rangkaian interleaved flyback dengan klem aktif tunggal pada area kerja keluaran 350W. Topologi yang digunakan diadaptasi dari penelitian (Alimadadi,2009) dengan melakukan beberapa penyesuaian komponen dan parameter rangkaian. Dapat diketahui bahwa penyusunan rangkaian interleaved flyback dengan spesifikasi tertentu hanya dapat digunakan pada area kerja tertentu pula. Oleh karena itu perlu adanya beberapa penyesuaian baik dari perhitungan nilai komponen, jumlah komponen dan pemasangan komponen.

Topologi serta susunan komponen pada penelitian (Alimadadi,2009) tidak serta merta dapat diaplikasikan begitu saja untuk area kerja 350W. Hal demikian dapat diketahui dari hasil efisiensi yang didapatkan begitu rendah yaitu kurang dari 50\%. Gambar. 3 adalah gambar topologi rangkaian interleaved flyback dengan klem aktif tunggal usulan. Yang mana saklar yang digunakan adalah N-MOSFET untuk saklar 1 dan P-MOSFET pada saklar 2. Sedangkan pada penelitian 
(Alimadadi, 2009) saklar yang digunakan adalah N-MOSFET untuk saklar 1 dan saklar 2. Gambar. 4 merupakan perbandingan tegangan pada saklar 1 dan 2 pada rangkaian usulan dan referensi. Gambar. 5 merupakan perbandingan arus pada saklar 1 dan 2 usulan dan referensi.
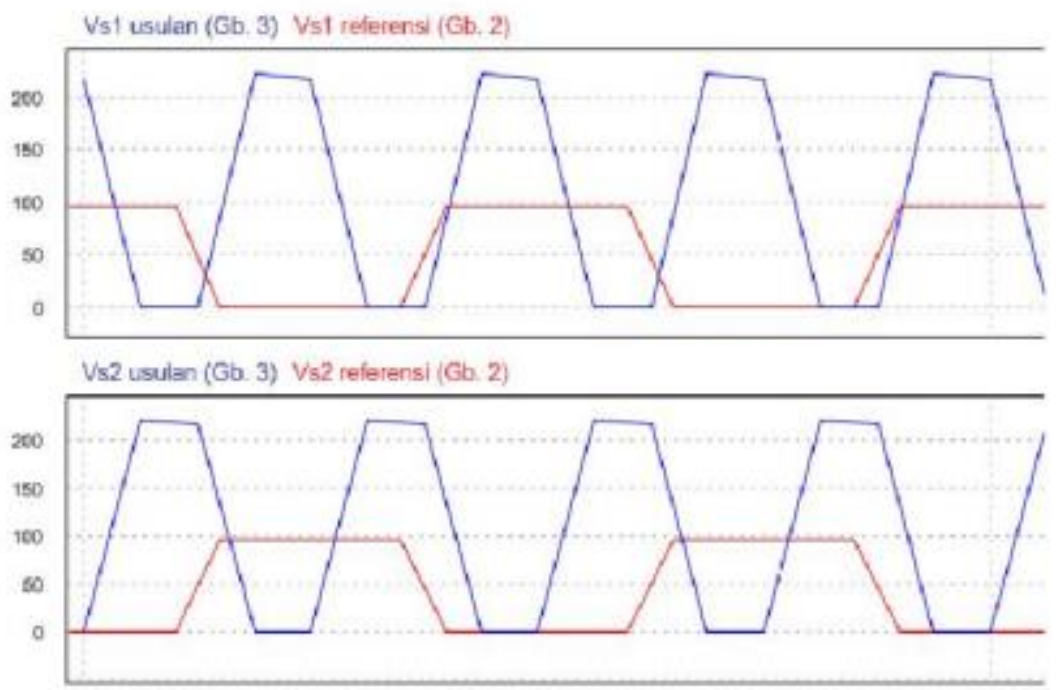

Gambar. 4. Diagram perbandingan tegangan pada S1 dan S2 usulan serta referensi.

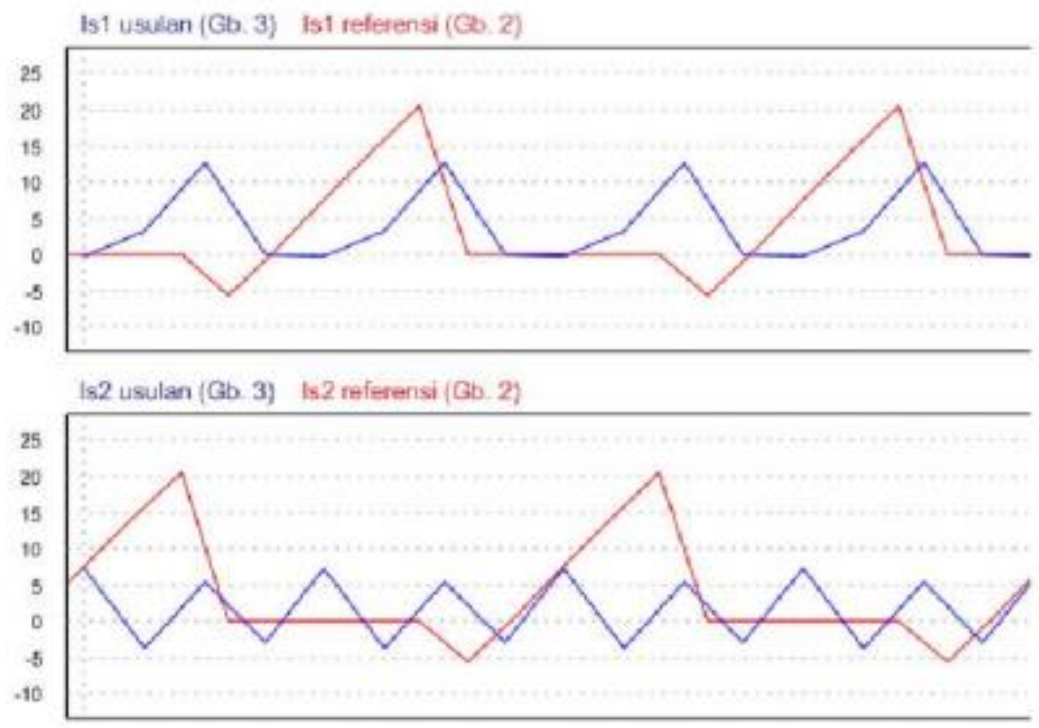

Gambar. 5. Diagram arus pada S1 dan S2 usulan serta referensi. 
Nilai arus saklar 1 dan saklar 2 dengan menggunakan topologi penelitian digunakan identik sebagaimana yang ditunjukkan pada Gambar. 5. Adapun pada rangkaian usulan saklar yang digunakan adalah N-MOSFET untuk saklar 1 dan PMOSFET untuk saklar 2 nilai arus yang diperoleh memiliki nilai yang hampir sama.

Ketika menggunakan P-MOSFET pada rangkaian pensaklaran beban, kaki drain terhubung langsung dengan beban sedangkan kaki source terhubung pada tegangan input (AND9093/D,2014). Begitu halnya dengan pemasangan NMOSFET yang secara umum dimana kaki drain terhubung kepada beban sedangkan kaki source terhubung pada ground.

Adapun alur kerja arus rangkaian pada rangkaian usulan tidak jauh berbeda dengan penelitian (Alimadadi, 2009), akan tetapi perbedaan terletak pada nilai arus yang mengalir pada saklar 2. Dimana turunnya nilai arus disebabkan karena tahanan pada N-MOSFET yang berlawanan dengan arus dari input DC. Gambar. 6. menunjukkan pemasangan MOSFET pada aplikasi pensaklaran beban secara dasar. (Alimadadi, 2009) mengalami perbedaan nilai meskipun kedua saklar yang digunakan identik sebagaimana yang ditunjukkan pada Gambar. 5. Adapun pada rangkaian usulan saklar yang digunakan adalah $\mathrm{N}$ MOSFET untuk saklar 1 dan PMOSFET untuk saklar 2 nilai arus yang diperoleh memiliki nilai yang hampir sama. Ketika menggunakan PMOSFET pada rangkaian pensaklaran beban, kaki drain terhubung langsung dengan beban sedangkan kaki source terhubung pada tegangan input (AND9093/D,2014). Begitu halnya dengan pemasangan NMOSFET yang secara umum dimana kaki drain terhubung kepada beban sedangkan kaki source terhubung pada ground.

Adapun alur kerja arus rangkaian pada rangkaian usulan tidak jauh berbeda dengan penelitian (Alimadadi, 2009), akan tetapi perbedaan terletak pada nilai arus yang mengalir pada saklar 2. Dimana turunnya 
nilai arus disebabkan karena tahanan pada N-MOSFET yang berlawanan dengan arus dari input DC. Gambar. 6. menunjukkan pemasangan MOSFET pada aplikasi pensaklaran beban secara dasar.

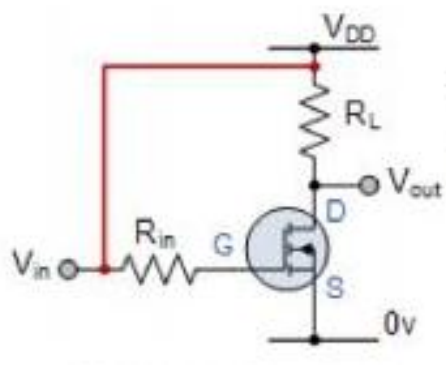

N-MOSFET

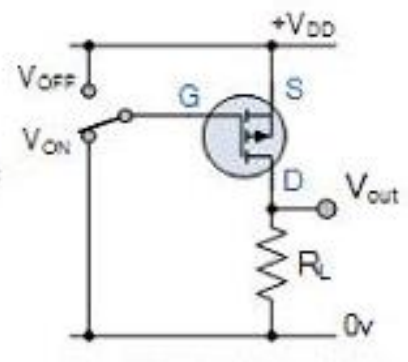

P-MOSFET

Gambar. 6. P-MOSFET dan N-MOSFET.

Pada rangkaian usulan N-MOSFET yang terpasang pada saklar 2 (S2) diganti dengan P-MOSFET. Dimana pada karakteristiknya titik source terhubung pada sumber tegangan positif VDC dan titik drain terhubung pada beban flyback 2. Setelah adanya penggantian jenis MOSFET tersebut maka diperoleh arus yang tidak jauh berbeda dengan arus yang mengalir pada saklar 1 (S1).

\section{OPERASI PADA RANGKAIAN}

Pada simulasi, digunakan beberapa asumsi dalam analisis rangkaian sebagaimana berikut :

- Semikonduktor yang digunakan ideal.

- Hambatan dalam, kebocoran induktansi sekunder pada trafo dihilangkan.

- kebocoran induktansi (Lkg) diasumsikan $1 \%$ dari induktansi pemagnetan $(\mathrm{Lm})$.

- kapasitor klem $(\mathrm{Ccl})$

Berikut adalah alur kerja dari rangkaian interleaved flyback dengan klem aktif tunggal usulan yang terbagi ke dalam 2 interval 
- Interval 1 : S1 nyala dan S2 mati. Arus pada Lkg1 dan Lm1 meningkat dimana energi tersimpan pada keduanya (inti trafo 1). Arus pada $\mathrm{Lkg} 2$ menurun sementara $\mathrm{Ccl}$ mengisi. Energi yang pada tahap sebelumnya tersimpan di Lkg2 sedang diklem, energi yang tersimpan pada Lm2 tahap sebelumnya sedang ditransfer ke sisi sekunder. Alur kerja ditunjukkan pada Gambar.7.

- Interval 2 : S1 mati S2 nyala. Aarus di Lkg2 dan Lm2 meningkat dimana energi tersimpan pada keduanya (inti trafo 2). Energi akan digunakan pada Interval 1. Arus pada Lkg1 menurun sementara Ccl mengisi. Energi yang pada tahap sebelumnya tersimpan pada Lkg1 sedang diklem, energi yang tersimpan pada Lm1 sedang ditransfer ke sisi sekunder. Alur kerja ditunjukkan pada Gambar.8

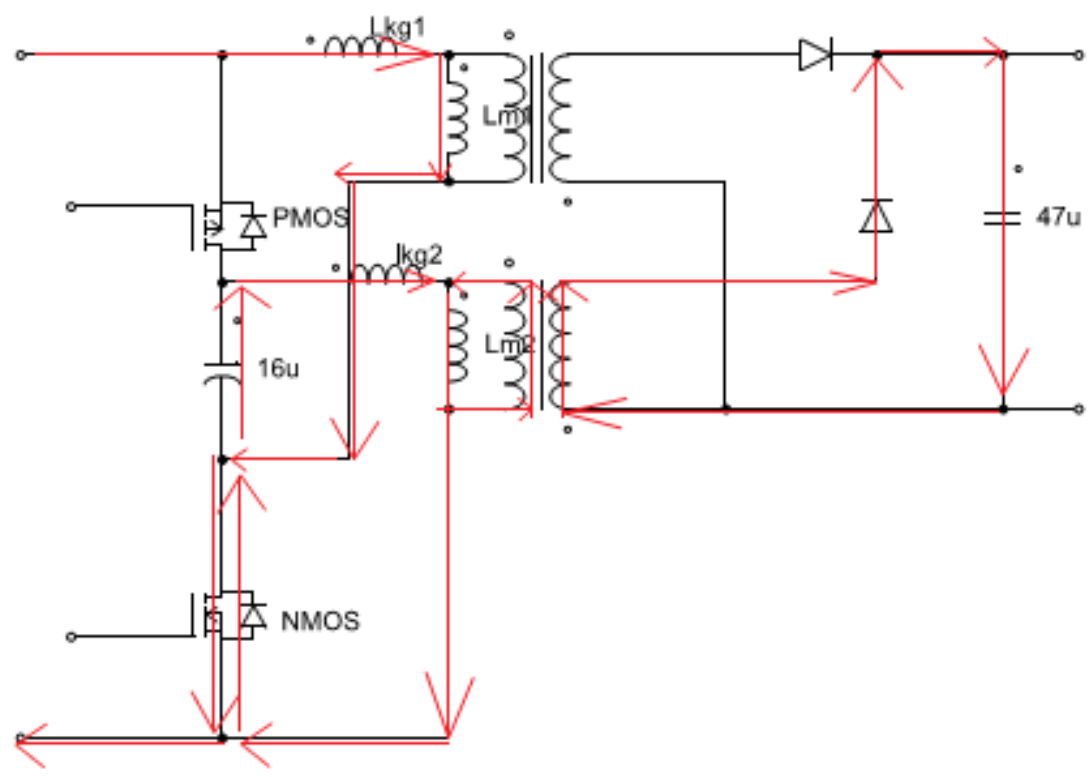

Gambar. 8. Interval 2 


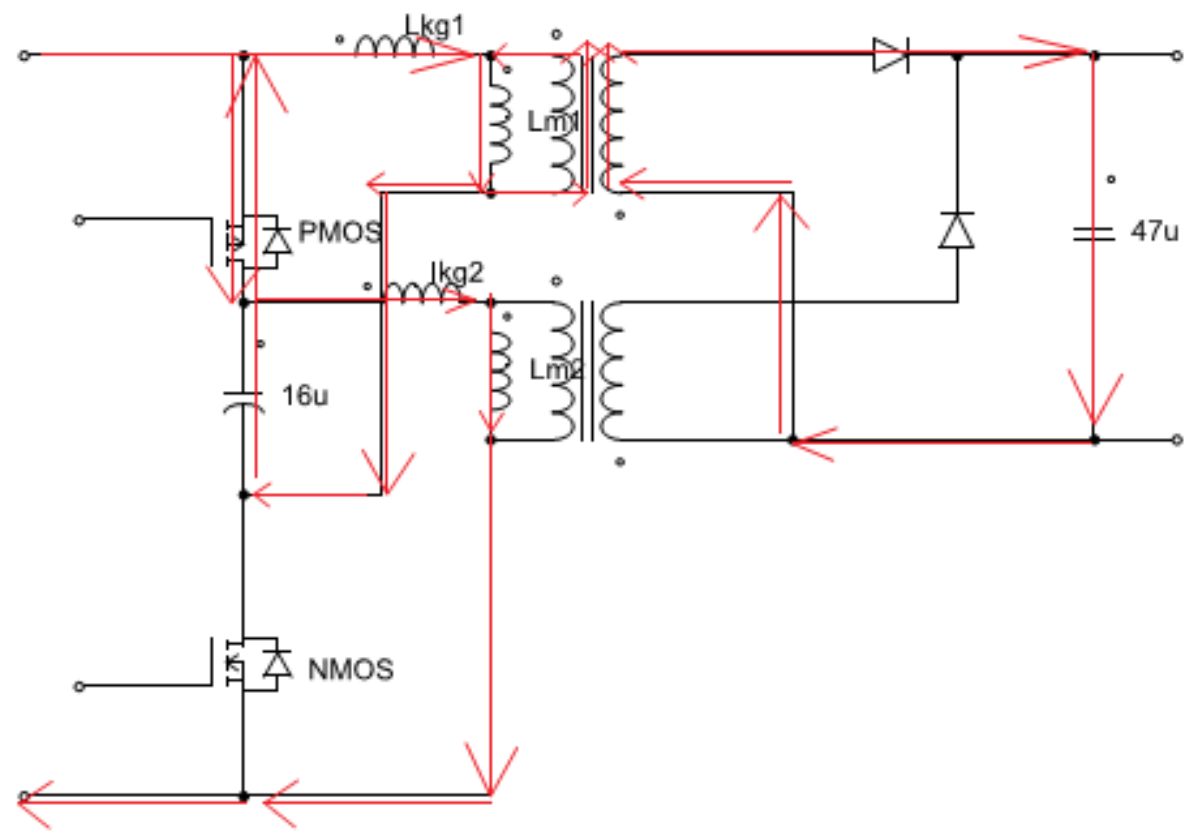

Gambar. 8. Interval 2.

\section{PENSAKLARAN}

Pada penelitian ini rangkaian konverter hanya menggunakan dua buah saklar semikonduktor yaitu MOSFET tipe NMOS dan PMOS. Kedua saklar tersebut digunakan sebagai saklar utama flyback serta sebagai saklar pengatur klem aktif.

Sinyal pembangkit Pulse Width Modulation (PWM) dibentuk dari sinyal referensi DC dan dua buah sinyal pembawa (sinyal segitiga) yang berbeda fase. Gambar rangkaian blok pengontrol sinyal pembangun PWM ditunjukkan Gambar. 9. Ada pun beda fase dari sinyal pembawanya adalah $180^{\circ}$. Untuk kontrollernya digunakan Proportional Integral (PI).

Diagram sinyal segitiga ditunjukkan pada Gambar. 10. Dengan jelas tampak sinyal referensi DC dan sinyal pembawa yaitu sinyal segitiga. Adapun frekuensi yang digunakan pada sinyal pembawanya adalah masing-masing 100 KHz. Pada topologi flyback semakin tinggi frekuensi yang digunakan maka akan semakin kecil desain trafonya. 


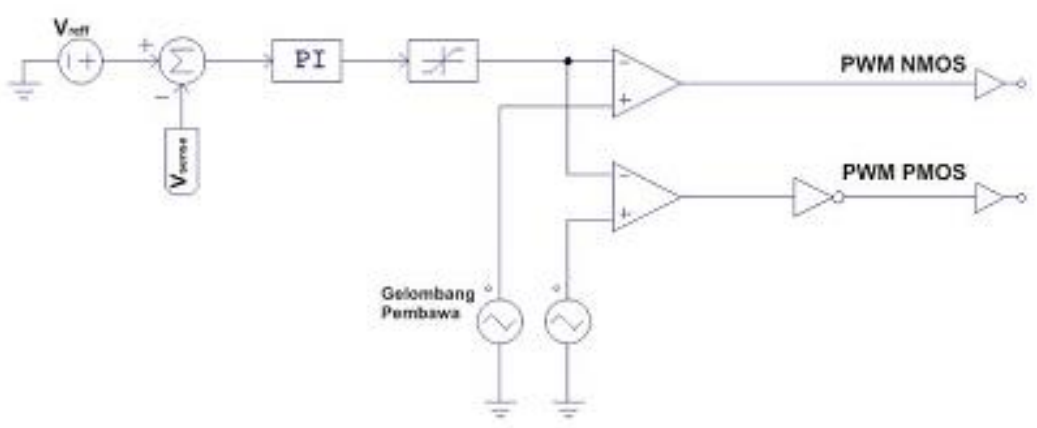

Gambar. 9. Blok pengontrol sinyal pembangun PWM.

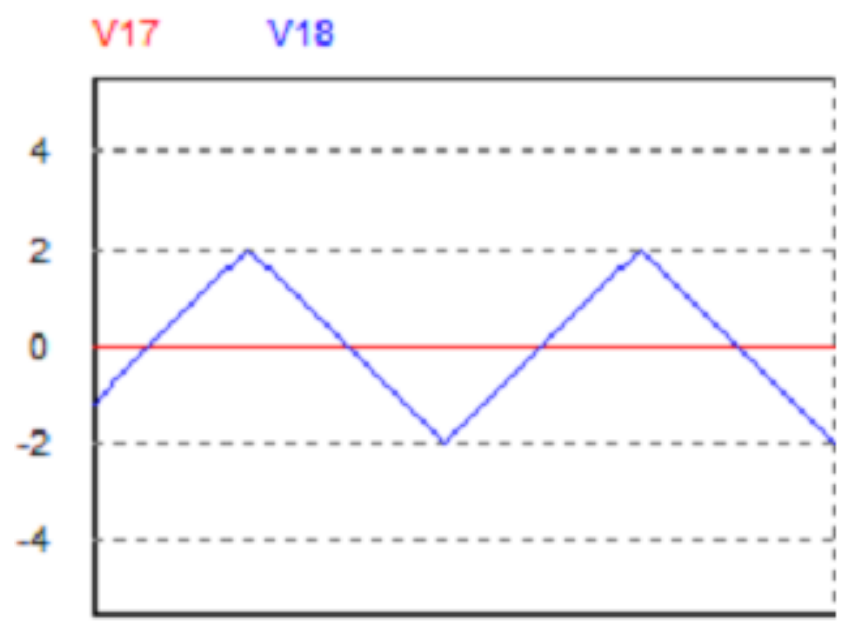

Gambar. 10. Sinyal segitiga

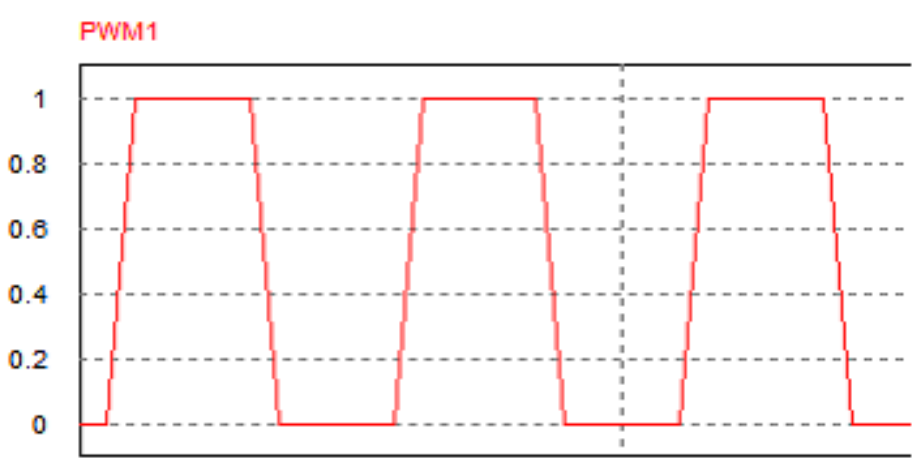

Gambar. 11. Sinyal PWM saklar 1 (NMOS). 


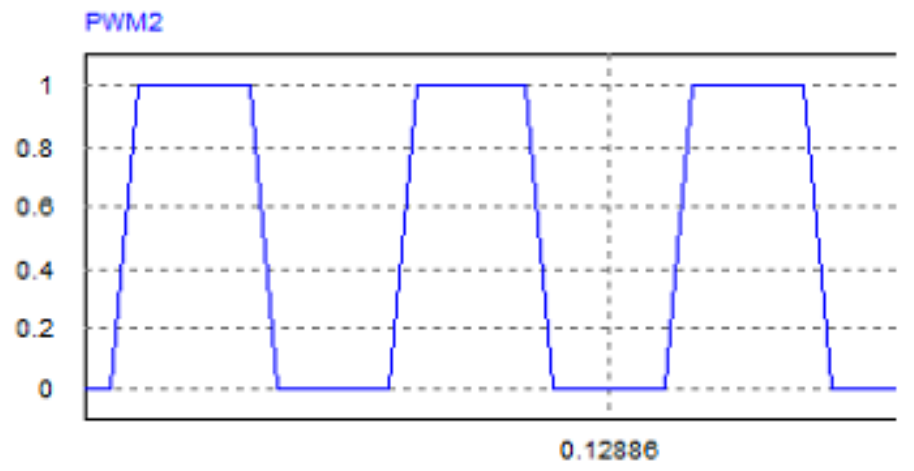

Gambar. 12. Sinyal PWM saklar 2 (PMOS).

Perbandingan dari sinyal referensi DC dan sinyal segitiga pembawa dapat dilihat pada Gambar. 10. Gambar. 11 dan Gambar. 12. Merupakan gambar sinyal PWM pada NMOS dan pada gerbang PMOS.

Diagram tegangan pada gate $\mathrm{S} 1$ dan $\mathrm{S} 2$ terlihat sama tetapi memiliki arti yang berbeda. Hal tersebut dikarenakan oleh perbedaan tipe MOSFET yang digunakan antara NMOS dan PMOS. Untuk NMOS dipasang sebagai S1 sedangkan PMOS dipasang sebagai S2. Dimana NMOS akan ON ketika Vgate >Vth sedangkan PMOS akan ON saat $\mathrm{V}_{\text {gate }}<\mathrm{V}_{\text {th }}$.

\section{SIMULASI}

Dalam perancangan rangkaian yang akan digunakan dalam simulasi perlu adanya penentuan beberapa parameter terlebih dahulu. Hal yang perlu ditentukan terlebih dahulu adalah nilai nilai dari D, Np dan Ns yang tertuang dalam rumus :

$$
\frac{V_{\text {out }}}{V_{\text {in }}}=\frac{N_{s}}{N_{p}} \times \frac{D}{1-D}
$$

D merupakan duty cycle yang bekerja pada MOSFET, Np dan Ns merupakan jumlah lilitan pada sisi primer dan sekunder trafo. Gambar. 13. merupakan rangkaian lengkap dari interleaved flyback dengan klem aktif tunggal. 


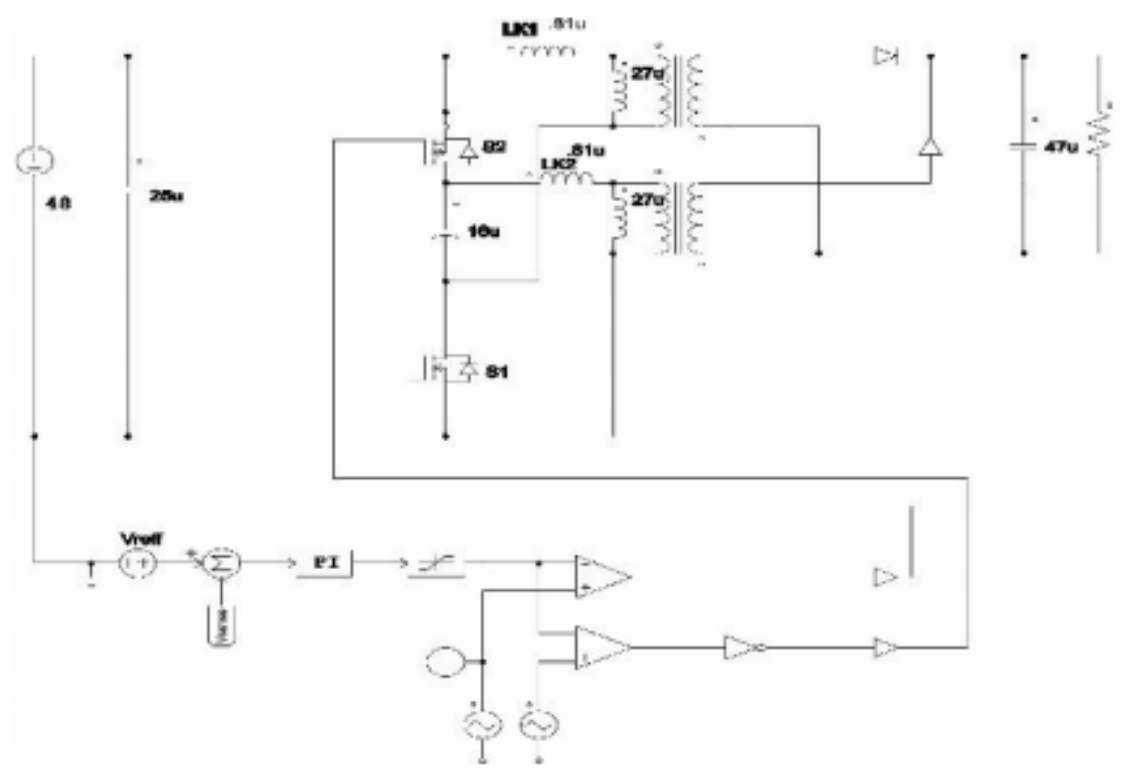

Gambar. 13. Rangkaian simulasi interleaved flyback dengan klem aktif tunggal.

Dalam menentukan desain induktor perlu ditentukan terlebih dahulu $i_{\text {in }}$ (arus input) yang bekerja dimana diperoleh dengan rumus :

$$
i_{\text {in }}=\frac{P_{\text {out }}}{V_{\text {in }} \times \eta}
$$

Pout adalah daya keluaran yang diinginkan, Vin adalah tegangan DC masukan dan $\eta$ adalah efisiensi yang diharapkan. Dari persamaan tersebut maka dapat ditentukan besarnya magnetisasi induktansi $(\mathrm{Lm})$ yang bekerja pada trafo yaitu dengan persamaan :

$$
L_{m}=\frac{V_{\text {in }}}{\Delta i_{\text {in }}} \times \frac{D}{f_{s}}(3)
$$

fs merupakan frekuensi switching yang bekerja pada MOSFET. Untuk induktansi bocor (Lkg) diasumsikan sebesar 3\% dari Lm. Dari besarnya induktansi bocor dapat diperoleh persamaan untuk mencari besarnya kapasitor klem yang ditunjukkan :

$$
C_{c l} \geq \frac{(1-D)^{2}}{\pi^{2} \times L_{l k g} \times 2 f_{s}^{2}}
$$


Sedangkan pada sisi sekunder atau output dipasang sebuah kapasitor output guna mengurangi ripple tegangan. Pada standarnya ripple tegangan yang diijinkan biasanya adalah sebesar $1 \%$ dari Vout. Adapun persamaannya adalah sebagai berikut :

$$
C_{\text {out }} \geq \frac{D}{R \times 1 \% \times V_{\text {out }} \times 2 f_{s}}
$$

$\mathrm{R}$ merupakan beban. Rincian dari parameter-parameter yang digunakan dalam rangkaian simulasi tertuang pada Tabel 1 .

Tabel 1. Parameter Komponen Simulasi.

\begin{tabular}{|l|l|}
\hline$V_{\text {in }}$ & $48 \mathrm{~V}$ \\
\hline $\mathrm{V}_{\text {out }}$ & $220 \mathrm{~V}$ \\
\hline $\mathrm{P}_{\text {out }}$ & $350 \mathrm{~W}$ \\
\hline $\mathrm{f}_{\mathrm{s}}$ & $100 \mathrm{kHz}$ \\
\hline $\mathrm{D}$ & $50 \%$ \\
\hline $\mathrm{L}_{\mathrm{m}}$ & $27 \mu \mathrm{H}$ \\
\hline $\mathrm{Lkg}$ & $0.81 \mu \mathrm{H}$ \\
\hline $\mathrm{C}_{\text {out }}$ & $47 \mu \mathrm{F}$ \\
\hline $\mathrm{N}$ & $10 / 50$ \\
\hline $\mathrm{S} 1$ & $\mathrm{~N}-\mathrm{MOSFET}$ \\
\hline $\mathrm{S} 2$ & $\mathrm{P}-\mathrm{MOSFET}$ \\
\hline $\mathrm{Ccl}$ & $16 \mu \mathrm{F}$ \\
\hline
\end{tabular}

Pada simulasi dibandingkan antara rangkaian interleaved flyback dengan klem aktif konvensional, rangkaian referensi (Alimadadi,2009) dan rangkaian usulan interleaved flyback dengan klem aktif tunggal dimana didapat hasil dengan rincian yang tertuang pada Tabel 2., Tabel 3. dan Tabel 4.

Dari hasil simulasi pada beberapa daya keluaran maka diperolehlah hasil yang dapat digambarkan dalam bentuk diagram grafik yang ditunjukkan pada Gambar. 14.

\section{HASIL DAN PEMBAHASAN}

Hasil berupa data penelitian yang telah diolah dan dituangkan dalam bentuk tabel, grafik, foto atau gambar. Pembahasan berisi hasil analisis dan hasil penelitian yang dikaitkan dengan struktur pengetahuan yang telah mapan (tinjauan pustaka 
yang diacu oleh penulis), dan memunculkan teori-teori baru atau modifikasi terhadap teori - teori yang telah ada.

Tabel 2. Hasil Simulasi Interleaved Flyback dengan Klem Aktif Konvensional.

\begin{tabular}{|l|l|l|l|}
\hline $\mathrm{R}_{\text {out }}(\Omega)$ & $\begin{array}{l}\mathrm{P}_{\text {out }} \\
(\text { Watt) }\end{array}$ & $\mathrm{P}_{\text {in }}$ (Watt) & $\begin{array}{l}\text { Effisiensi } \\
(\%)\end{array}$ \\
\hline 276.5 & 175 & 200 & 87.5 \\
\hline 242 & 200 & 227 & 88.1 \\
\hline 193.6 & 250 & 293 & 85.3 \\
\hline 161.3 & 300 & 348 & 86.2 \\
\hline 138.2857 & 350 & 400 & 87.5 \\
\hline
\end{tabular}

Tabel 3. Hasil Simulasi Interleaved Flyback dengan Klem Aktif Tunggal Referensi

\begin{tabular}{|l|l|l|l|}
\hline$R_{\text {out }}(\Omega)$ & $P_{\text {out }}$ (Watt) & $P_{\text {in }}$ (Watt) & $\begin{array}{l}\text { Effisiensi } \\
(\%)\end{array}$ \\
\hline 302.28 & 175 & 761 & 22.9 \\
\hline 264.5 & 200 & 771 & 25.9 \\
\hline 211.6 & 250 & 776 & 32.2 \\
\hline 176.33 & 300 & 780 & 38.4 \\
\hline 151.14 & 350 & 775 & 45.2 \\
\hline
\end{tabular}

Tabel 4. Hasil Simulasi Interleaved Flyback dengn Klem Aktif Tunggal Usulan.

\begin{tabular}{|l|l|l|l|}
\hline$R_{\text {out }}(\Omega)$ & $P_{\text {out }}($ Watt) & $\begin{array}{l}P_{\text {in }} \\
(\text { Watt) }\end{array}$ & $\begin{array}{l}\text { Effisiensi } \\
(\%)\end{array}$ \\
\hline 276.5 & 175 & 196 & 89.3 \\
\hline 242 & 200 & 222 & 90.1 \\
\hline 193.6 & 250 & 279 & 89.6 \\
\hline 161.3 & 300 & 331 & 90.6 \\
\hline 138.2857 & 350 & 381 & 91.8 \\
\hline
\end{tabular}

Gambar. 14. Grafik perbandingan daya keluaran 


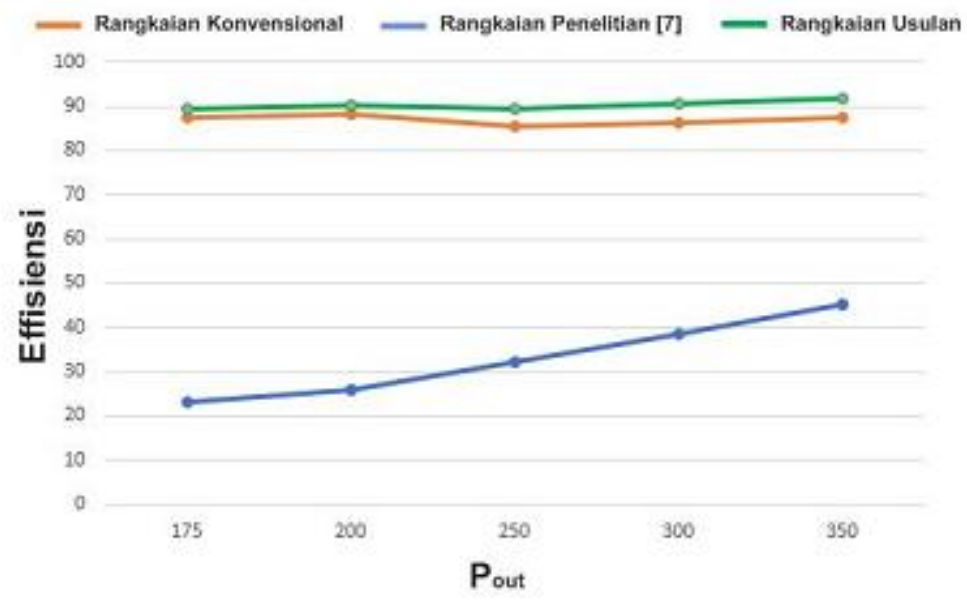

Gambar. 14. Grafik perbandingan daya keluaran

Dari grafik hasil simulasi pada beberapa nilai daya keluaran dapat dilihat bahwa penggunaan klem aktif tunggal pada rangkaian interleaved flyback yang diusulkan didapatkan nilai efisiensi yang lebih baik yaitu $91.8 \%$ pada daya keluaran $350 \mathrm{~W}$.

\section{KESIMPULAN}

Pada penelitian ini, rangkaian interleaved flyback dengan klem aktif tunggal telah diusulkan dan disimulasikan. Topologi rangkaian pada penelitian (Alimadadi, 2009) yang bekerja pada area daya keluaran 500 W diadaptasi ke dalam area kerja 350 W. Hasil simulasi pada rangkaian penilitian (Alimadadi,2009) di area kerja daya keluaran $350 \mathrm{~W}$ menunjukkan efisiensi yang rendah kurang dari $50 \%$. Turunnya efisiensi tersebut disebabkan oleh adanya penurunan nilai arus pada saklar 2. Turunnya nilai arus yang mengalir pada saklar 2 dapat diatasi dengan mengganti saklar 2 yang mulanya menggunaka N-MOSFET menjadi P-MOSFET. Topologi rangkaian usulan disimulasikan pada area kerja $350 \mathrm{~W}$ dengan Vout 220 V diperoleh efisiensi sebesar $91.8 \%$.

\section{DAFTAR PUSTAKA}

Watson, R., Hua, G. C., Lee, F. C. 1996. "Characterization of an active clamp flyback topology for power factor correction applications," IEE Trans. Power Electron., vol.11, no.1, pp.191-198. 
Pinheiro, H., Jain P. K., and Joos, G. 2002. "A Comparison of UPS for Powering Hybrid Fiber/Coaxial Networks," IEEE Trans. Power Electronics, vol. 17, no. 3, pp. 389-397.

Chin, C., Knights, M. A. 1995."Interleaving technique in distribute power conversion systems," IEEE Trans. Circuits and Systems. I Fundam Theory Appl., vol. 42, no. 5, pp. 245-251.

Li, W. , Shi, J., Hu, M., He, X. 2007. ”An Isolated Interleaved Active-Clamp ZVT Flyback-Boost Converter with Coupled Inductors", IEEE European Conference on Power Electronics and applications.

Parampreet, K. T. 2014. "Design of Low Voltage Active Electric Accumulator With Integrated DC-DC Converter for Control and Protection," A Thesis MCMASTER UNIVERSITY CANADA.

Note, A. 2012. "Grid - Connected Solar Microinverter Reference Design," MICROCHIP AN-1444.

Alimadadi, M., Dunford, W. 2009. “A Merged Interleaved Flyback PFC Converter with Active Clamp and ZVCS". PEDS2009. Department of Electrical and Computer Engineering University of British Columbia

Note A.. 2014. "Using MOSFET in Load Switch Applications," ON Semiconductor AND9093/D. 